\title{
Waardenburg Syndrome Type 2
}

National Cancer Institute

\section{Source}

National Cancer Institute. Waardenburg Syndrome Type 2. NCI Thesaurus. Code C75009.

A rare autosomal dominant syndrome caused by mutations in the MITF and SNAI2 genes. It has all of the features of Waardenburg syndrome Type 1 except dystopia canthorum. 